\title{
Daniel at the Beauty Pageant and Esther in the Lion's Den: Literary Intertextuality and Shared Motifs between the Books of Daniel and Esther
}

\author{
MatTheW Michael (STEllenbosch University AND NASARAWA \\ STATE UNIVERSITY, NigERIA)
}

\begin{abstract}
The present paper reads the books of Esther and Daniel as polemic writings of the Persian period which subtly seek to undermine the rhetoric of each other. Since the postexilic environment posed an enormous challenge to the Jewish identity, the great need to preserve this identity became a reoccurring motif in most postexilic compositions. Crystallizing this postexilic discourse, however, the books of Esther and Daniel propose two opposing attitudes to the problem of Jewish identity. While the book of Esther generally advocates the extreme adoption and even marriage to these foreign cultures, the book of Daniel particularly its narrative section (1-6) rejects this particular perspective, and largely promotes a defiant disposition towards the dominant culture. Through intertextual connections, the paper engages the various motifs in Esther, and notes also the subtle engagement and even subversion of these motifs in Daniel.
\end{abstract}

KEYWORDS: Esther; Daniel; Characterization; Intertextuality; Polemics; Shared Motifs; Postexilic.

\section{A INTRODUCTION}

Intertextuality has become a defining field of $\mathrm{HB}$ in modern scholarship with increasing publications committed to the intertextual readings of the HB. ${ }^{1}$ While this particular approach has a tendency to degenerate into some kind of subjective modern Midrash or the uncritical resuscitation of the dead rabbinic exegesis of ancient times, these synchronic readings in most cases have generally opened up new horizons in the crafting of biblical narrative because the inter-

* Article submitted: 15/10/2016; article accepted: 22/02/2016. Matthew Michael, "Daniel at the Beauty Pageant and Esther in the Lion's Den: Literary Intertextuality and Shared Motifs Between the books of Daniel and Esther," OTE 29/1 (2016): 116132. DOI: http://dx.doi.org/10.17159/2312-3621/2016/v29n1a8

1 See Geoffrey D. Miller, "Intertextuality in Old Testament Research," CBR 9/3 (2010): 283-309. See also Cynthia Edenburg, "Intertextuality, Literary Competence, and the Question of Readership: Some Preliminary Observations," JSOT 35/4 (2010): 131-148; Hava Shalom-Guy, "Three-Way Intertextuality: Some Reflections of Abimelech's Death at Thebez in Biblical Narrative," JSOT 34/4 (2010): 419-432. 
textual links between biblical stories have often had the original signatures of the authors/redactors of the HB. ${ }^{2}$ In a general sense, intertextuality exists in every literary composition whether clearly expressed or unexpressed because the process of literary composition itself invariably provides justification for this exercise. ${ }^{3}$ Amy Scheinerman rightly observed,

Texts are not written in a vacuum any more than their authors live hermetically sealed lives apart from society and all other literature. Every text bears the marks of external influence. Certainly texts are shaped by their author's worldview and personality, but also by other texts. They may bear evidence of influence of another text, allude to another text, or be in conversation with another text, responding to issues it raises. ${ }^{4}$

To be more precise, biblical authors appear to borrow motifs from each other, and it is increasingly recognized that biblical authors use common motifs and literary conventions in their representations of the story world. ${ }^{5}$ For the biblical narrators, the literary environment in terms of similarity of language use, cultural space and the polemic agenda of most biblical narratives increase the possibility of intertextual links with motifs, characterization and polemics

2 For example, Max Rogland, "Interpreting אר in Genesis 2.5-6: Neglected Rabbinic and Intertextual Evidence," JSOT 34/4 (2010): 379-393; James A. Loader, "Intertextuality in Multi-Layered Texts of the Old Testament," OTE 21/2 (2008): 391-403; Patricia Trull, "Intertextuality and the Hebrew Scriptures," CBR 8 (2000): 59-90.

3 In literary studies, literary theorists in modern times have continually acknowledged the intertextual character of every written or non-written texts such as works of arts and film. On the connection of "intertextuality" to literary theorists Julia Kristeva, Mikhail Bakhtin, Ronald Barthes and Gérard Genette, see Mohammed K. Shakib, "Inevitability of Arts from Inter-textuality," IJEL 4/1 (2013): 1-5; Niall McKay, "Status Update: The Many Faces of Intertextuality in New Testament Study," R\&T 20 (2013): 84-106.

4 See Amy Scheinerman, "Exodus, Esther and Maccabees in Conversation: 'They Tried to Kill us; We Survive; Let's Eat," CCAR: RJQ (2013): 3.

5 The synchronic reading of the pericopes and the perceived intertextual connections between books has clearly generated new perspectives and insightful angles in the analyses of biblical books. While "intertextuality" has become fashionable term in modern scholarship on the HB, its definition has generally remained elusive. There are two perspectives in the usage of "intertextuality" in literary studies. The first use of "intertextuality" is generally to describe observations by any reader on text or nonwritten texts such as works of arts and film which seek to establish "relationship between texts regardless of genetic dependence" [see Mark Biddle, "Ancestral Motifs in 1 Samuel 25: Intertextuality and Characterization," JBL 121/4 (2002): 619]. The second use of "intertextuality" presents the term as narrative clues in a text which the narrator intends that his/her readers will discover and make the needed connection between parts or forms outside of the composition read. For these two different uses of "intertextuality" in the study of the HB see Miller, "Intertextuality in Old Testament Research," 283-309. See also Edenburg, "Intertextuality," 131-148. 
of preceding stories repeated and projected in other books within the HB. ${ }^{6}$ On this literary practice, Robert Alter has shown, for example, the common literary convention whereby biblical narrators framed their stories in the same literary scene or projected on their characters repeated characterizations which he has aptly described as the type-scene. ${ }^{7}$ The type-scene, according to Alter, may be adjusted and recontextualized, but the type-scene exercises a formidable impact in the characterization and storytelling traditions of biblical narrators. Alter has shown the presence, role and the intertextual connection between type-scenes across various biblical stories in the HB. ${ }^{8}$ Placed within these contemporary studies, however, there are no studies which have independently explored the intertextual connections between the representations and story plot of the book of Esther and Daniel. Even though these two books are both late compositions in the biblical canon, shared the same postexilic environment, espouse the same rhetoric in terms of protection for the Jewish identity against dominant foreign culture, preservation in the midst of persecution/annihilation, modern scholarship has largely ignored the intertextual connections between the two books. Beyond the commonality of their postexilic environment, the present paper shows important intertextual connections between the two books which clearly suggest that common motifs, representation and intertextual relationships exist between the two books.

\section{B INTERTEXTUAL STUDIES IN ESTHER AND DANIEL}

To describe the various works in modern scholarship on Esther and Daniel will be difficult to rehearse here because of the limited scope of the present study. ${ }^{9}$ However, we situate the present work in the confinement of dominant intertextual studies done in recent times on the two books. Beginning with the book of Esther, David G. Firth has described the intertextual connection between the book of Esther and Samuel. For example, the representation of King Ahasuerus and Haman in Esther $(1: 10 ; 5: 9)$ as "merry with wine." The same expression is used to describe Nabal and Ammon signalling their downfall (1 Sam 25:36 and

6 In biblical narrative, there is the use of intertextual links between biblical stories for polemic purposes. For this study see Yairah Amit, Hidden Polemics in Biblical Narrative (trans. Jonathan Chipman; BibInt 25; Leiden: Brill, 2000); See Diana Adelman, "Hidden Ancestral Polemics in the Book of Genesis," Words, Ideas, and World (ed. Athalya Brenner and Frank H. Polak; Sheffield: Phoenix, 2012), 32-53.

7 See Robert Alter, The Art of Biblical Narrative (New York: Basic Books, 2011), 87-117.

8 The studies of biblical type-scene have now become common. On these studies see Min S. Kee, “The Heavenly Council and its Type-scene," JSOT 31/3 (2007): 257273.

9 Concerning the treatment of the narrative world of the two books as a way of life see W. Lee Humphreys, "A Life-Style for Diaspora: A Study of the Tales of Esther and Daniel,” JBL 92 (1973): 211-23. 
2 Sam 13:28). ${ }^{10}$ According to Firth, Ahasuerus and Haman are described with the same phraseology and condition of Nabal and Ammon "because those who are in this condition act with folly" and this characterization generally attends the representation of Ahasuerus and Haman in the book of Esther. ${ }^{11} \mathrm{He}$ also observed the description of Haman with the epithet "Agagite" (3:1, 10, 8:3, 5, 9:24), and its intertextual connection to the story of Agag in 1 Sam 15. It seems the narrator of Esther wanted to restage and continue the Saul and Agag tension in the book of 1 Samuel with Haman in the character zone of Agag and Esther/Mordecai connected to the ancestry of Saul. ${ }^{12}$

In the same way, Yitzhak Berger has drawn attention to this same motif in his description of the intertextual connection between the book of Esther and 1 Samuel. He suggests the representation of the heroine Esther was done to overturn "the pivotal failure of Saul" in the book of Samuel. ${ }^{13}$ He notes the subtle connection between the story of Esther's rise to power and the report of Saul's rise to kingship in 1 Samuel. ${ }^{14} \mathrm{He}$ also describes the larger connection between the stories of Saul, David and the echo of this representation in Esther particularly with the hanging of Haman's ten sons and the intertextual relationship to the killing of ten Saulides by David (2 Sam 21:8-9). ${ }^{15}$ He further went to show the literary connection between Saul and the surrounding stories of Nabal and the book of Esther. Berger also extends this same literary connection to the representation of Solomon in the book of $1 \mathrm{Kgs} 2$ particularly the revengeful killings of Joab and Adonijah by Solomon and the revenge of Esther/Mordecai in the book of Esther. ${ }^{16}$ Based on these allusions, Berger observed, "I conclude, then, that the allusions employed by the author of Esther pervade the story, and, in a consistent way, generate meaning that is funda-

10 David G. Firth, "When Samuel Meets with Esther: Narrative Focalisation, Intertextuality, and Theology," SThR 1/1 (2010): 23.

11 Firth, "When Samuel Meets with Esther," 24.

12 Firth, "When Samuel Meets with Esther," 25-26.

13 See Yitzhak Berger, "Esther and Benjaminite Royalty: A Study in Inner-Biblical Allusion," JBL 129/4 (2010): 627.

14 Berger, "Esther and Benjaminite Royalty," 628.

15 Berger, "Esther and Benjaminite Royalty," 637-644.

16 Noting the polemic character of the book in this perspective, Berger said, "In my opinion, by way of this final clause, the book of Esther thus draws attention to a fundamental difference between the revenge of David and Solomon and that of Esther and Mordechai. For all the triumphs and worthy traits of King David, his exercise of power brings bloodshed upon his own brethren, especially members of the rival tribe of Benjamin. The Benjaminite leadership in Esther, on the other hand, takes appropriate measures against the Jews' Agagite enemy and his adherents, while fostering peace and unity among all of its own kin." Berger, "Esther and Benjaminite Royalty," 644. 
mental to the book's objective." 17 This objective, according to Berger, is to settle the scores between the dynasties of David and Saul.

Similarly, Aaron Koller has shown the intertextual link between the representation of Esther to Joseph in Genesis, and Saul in 1 Samuel. ${ }^{18}$ Also, Amelia D. Friedman has engaged the intertextuality in Esther particularly from the representation of God as an absent character. ${ }^{19}$ On the other hand, G. J. Swart has described the intertextual connections between the representations of Esther to Rahab in Josephus. ${ }^{20}$ He observed,

...it is evident that Josephus, when writing his version of the Rahab story in Joshua 2, imagined the dynamics of Rahab's situation in a way very similar to that of Esther as he would later portray her story. Despite the absence of any explicit allusions, the similarities between these Josephan narratives - the common motifs, clusters of motifs, and the distinctive vocabulary - allow these texts to be read using an intertextual approach by which their respective interpretations are mutually enhanced. ${ }^{21}$

In addition, Scheinerman has described the common literary motifs between the book of Esther and the book of Exodus particularly the common motifs shared by Esther and Moses. ${ }^{22}$ She notes the similarities between Esther and Moses in terms of the concealing of their identities, and the quest to save their people from annihilation. She said, "Esther lives in the palace with the very man who set his seal on a decree to annihilate her and her people, the Jews. Esther is the queen of Persia though she is a Jew and not a Persian." In this regard, "[b]oth Moses, prince of Egypt, and Esther, queen of Persia, become members of the royal family, their Jewish identity a secret."23 In the same way, both Esther and Moses showed initial hesitation in saving their people from the annihilating threat. In both stories of Esther and Moses, enemies of the Israelites/Jews died in great numbers with no casualties among Esther/Moses' people. ${ }^{24}$ For Scheinerman, the narrative world of Exodus pre-

17 Berger, "Esther and Benjaminite Royalty," 644.

18 Aaron Koller, Esther in Ancient Thought (New York: Cambridge University Press, 2014).

19 Amelia D. Freedman, God as an Absent Character in Biblical Hebrew Narrative: A Theoretical Study (StBL 82; New York: Peter Lang, 2005), 87-119.

20 Gerhard J. Swart, "Rahab and Esther in Josephus: An Intertextual Approach," $A P B 17$ (2006): 50-65.

21 Swart, "Rahab and Esther in Josephus," 63.

22 Scheinerman, "Exodus," 3-23.

23 Scheinerman, "Exodus," 6.

24 She said, "The Book of Esther ends with the massacre of Persians who attack their Jewish neighbors. Remarkably, only Persians die in the fierce and bloody hand-tohand combat — not a single Jew is reported to have been killed. These Jews have the power to defend themselves, not only with their heads (Esther's wits and Mordecai's 
sents a God-centred act of redemption while in the book of Esther there is a dominant "human-centred" type of redemption. Thus, the book of Esther complements or even engages the dominant polemics and representation of a deitycentred redemption. Furthermore, Scheinerman shows also the influence of this description of redemption in Esther and its contending presence in the rabbinic writings. ${ }^{25}$ Similarly, this intertextual reading of Esther in relationship to Exodus in Scheinermann has found earlier expression in James A. Loader. ${ }^{26} \mathrm{He}$ notes the intertextual relationship between Esther and Exodus story. For Loader, "[t]he Esther story culminates in the Purim Festival as the Exodus Story culminates in Passover.",27

While preceding works have engaged the significant role of intertextual connection of the book of Esther to several stories in the Bible, the place of intertextuality in Daniel has also drawn scholarly interests. ${ }^{28}$ For example, Michael Segal, following after John J. Collins and L. F. Hartman and A. A. Di Leila, had generally noted the intertextual links between Daniel's interpretation of King Nebuchadnezzar's dreams in ch. 2, and Joseph's interpretation of Pharaoh's dreams in Gen 41. ${ }^{29}$ For Segal, Daniel is a "second Joseph." "30 The two stories, according to Segal, describe a foreign king who has a dream, and was troubled by this dream because he did not know the meaning (Dan 2:1; Gen 41:8). ${ }^{31}$ The foreign kings in both stories called upon the wise men and magicians to help with the interpretation of the dream (Dan 2:2-13; Gen 41:8). ${ }^{32}$ However, the wise men and magicians were unable to provide the kings with the interpretation of the dreams. In the two stories, one of the king's officers brought to the kings a Hebrew/Judean young man who claimed to have the

grit) but also with brute force: their hands brandish the weapons." See Scheinerman, "Exodus," 10.

25 Scheinerman, "Exodus," 10-23.

26 The reading by Loader follows after the earlier works of Gillis Gerleman in the 1960. See Gillis Gerleman, Esther (BKAT 21; Germany: Neukirchen-Vluyn: Neukirchener Verlag, 1966); Gillis Gerleman, Studien zu Esther (BibS[N] 48; Neukirchen-Vluyn: Neukirchener Verlag, 1974).

27 Loader, "Intertextuality in Multi-layered Texts," 400.

28 The book of Daniel presents "the first explicit evidence of canonical texts being read as scripture" in the quotation of Jer 29:10 in Dan 9:2. One would expect a formidable intertextuality within the book. See Hugh S. Pyper, "Reading in the Dark: Zechariah, Daniel and the Difficulty of Scripture," JSOT 29/4 (2005): 491-2.

29 John J. Collins, Daniel: A Commentary on the Book of Daniel (Hermeneia; Minneapolis: Fortress, 1993), 39-40; Louis F. Hartman and Alexander A. Di Leila, The Book of Daniel: A New Translation with Introduction and Commentary (AB 23; New York: Doubleday, 1978), 56.

30 Michael Segal, "From Joseph to Daniel: The Literary Development of the Narrative in Daniel 2," VT 59 (2009): 123.

31 Segal, "From Joseph to Daniel," 123-149.

32 Segal, "From Joseph to Daniel," 142. 
ability to interpret the kings' dreams (Dan 2:14, 24b-25; Gen 41:9-13). ${ }^{33}$ The youth recognizes God as the source of the interpretation for the king, and then proceeds to tell the kings the meaning of the dreams (Dan 2:25; Gen 41:14). In the two stories, according to Segal, the interpretations of the dreams are not for the personal benefits of the kings but the importance of the dreams transcend the lives of the kings to include their kingdoms. The kings rewarded the Hebrew young men with gifts and promotion (Dan 2:48; Gen 41:40-45). ${ }^{34}$ Considering these similarities, Segal said,

In light of all of these parallels, it has been correctly suggested that the Joseph story serves as a literary model for the Daniel tale, and was probably chosen since the former describes an Israelite or Jew in the Diaspora, who was able to succeed in the court of the foreign king. ${ }^{35}$

Similarly, Matthew S. Rindge had considered further subtle intertextual connections between the two stories of Joseph and Daniel. He described four groups of characters involved in the two stories namely

the ruler (Pharaoh/Nebuchadnezzar); the magicians and those who fail to interpret the dream; the interpreter of the dream (Joseph/Daniel); and the person who functions as an intermediary between the ruler and the interpreter (cupbearer/Arioch). ${ }^{36}$

He significantly notes the "specific similarities" in lexical and thematic connections which represent Daniel as "a new and improved Joseph." 37 For Rindge, the representation of Daniel 2 was to present Daniel as "an interpreter par excellence" because the plot of this story is "intensified" through Nebuchadnezzar's demand to be told the dream and the interpretations rather than just the interpretation as requested by Pharaoh in Joseph's story. ${ }^{38}$ Rindge also describes the connection between the stories and the superiority of Daniel over the Joseph's story particularly in the arena of the piety. Rindge said,

[a] noteworthy element in the Daniel narrative that is absent from Genesis 41 is the prayer of Daniel (2:17-23). His prayer is all the

33 Segal, "From Joseph to Daniel," 142.

34 Concerning these similarities see Choon-Leong Seow, Daniel (WestBC; Louisville: Westminster John Knox, 2003), 34-35; Aaron Wildavsky, Assimilation versus Separation: Joseph the Administrator and the Politics of Religion in Biblical Israel (New Brunswick, N.J.: Transaction, 1993), 127-28; Robert K. Gnuse, "The Jewish Dream Interpreter in a Foreign Court: The Recurring Use of a Theme in Jewish Literature," JSP 7 (1990): 29-53.

35 Segal, "From Joseph to Daniel," 142.

36 Matthew S. Rindge, "Jewish Identity under Foreign Rule: Daniel 2 as a Reconfiguration of Genesis 41," JBL 129/1 (2010): 90.

37 Rindge, "Jewish Identity under Foreign Rule," 90.

38 Rindge, "Jewish Identity under Foreign Rule," 90-92. 
more striking given the fact that not once, throughout Genesis 3750 , is Joseph ever portrayed as one who prays. ${ }^{39}$

Similarly, in terms of its relationship to imperial order, Rindge found the story of Daniel superior to the story of Joseph where "extreme assimilation" to the imperial order was emphasized. According to Rindge, Daniel presents a story of "moderate resistance" to the imperial order. ${ }^{40}$ On the other hand, Janwim Wesselius has drawn attention to the "intertextual links" between the books of Daniel and Ezra. ${ }^{41}$ Describing the book of Daniel as a "dossier" rather than a continuous story, he engaged the apparent discontinuities within the various literary units of the book. ${ }^{42}$ Concerning the intertextual character of Daniel, Wesselius said, “....in a number of cases, including the book of Daniel, biblical authors copied vital structural traits of other texts-which they subjected to a thorough literary analysis-for setting up the structural framework of the text being written. ${ }^{43}$ In particular, Wesselius described the close structuring of Daniel to fit the structuring of the book of Ezra, and the corresponding use of Aramaic and Hebrew in both of these two books. He observed,

It is noteworthy that [the book of Ezra] closely fits the profile which is sketched here of Daniel. Similar features include: a break in the middle between six episodes and four; a comparable distribution of Hebrew and Aramaic parts, and the use of Aramaic to link effectively the two halves, with five Aramaic documents before and one after the separation between the two parts. ${ }^{44}$

Similarly, Wesselius also recognizes some other "intertextual features" between the two books. For instance, "Nebuchadnezzar's golden statue in Daniel 3-six by sixty cubits which have amazed ancient and modern exegetes alike," according to Wesselius, looks "suspiciously like the dimensions of the Second Temple (sixty by sixty cubits according to Ezra 6:3), the foundations of which are laid in the parallel Ezra 3." ${ }^{45}$ Connecting these two objects, Wesselius notes that

Nebuchadnezzar's object of veneration is intertextually linked and contrasted with the place where faithful Jews like Daniel and his companions would pray after the Captivity, which would not have

\footnotetext{
39 Rindge, "Jewish Identity under Foreign Rule," 92.

40 Rindge, "Jewish Identity under Foreign Rule," 95.

41 Jan-Wim Wesselius, "The Writing of Daniel," The Book of Daniel: Composition

and Reception (ed. John J. Collins and Peter W. Flint; Leiden: Brill, 2001), 291-306.

42 Wesselius, "The Writing of Daniel," 298.

43 Wesselius, "The Writing of Daniel," 299.

44 Wesselius, "The Writing of Daniel," 299.

45 Wesselius, "The Writing of Daniel," 303.
} 
been possible had the statue featured more realistic dimensions such as $12 \times 60$ cubits or $6 \times 30$ cubits. $^{46}$

Thus, by these structural and individual elements in both books, Wesselius suggested an intertextual relationship between these two books.

In sum, it seems contemporary studies in both Esther and Daniel have in the study of the two books suggested the intertextual character of these two books to other biblical books, but the intertextual connection between these two books in themselves have not been pursued. With this in mind, the present study engages the thematic and shared motifs between the books of Esther and Daniel particularly the web of intertextual relationship which appeared to exist between these two books.

\section{SHARED MOTIFS AND INTERTEXTUALITY}

Beyond their locations in the postexilic environment, the intertextual relationship between Esther and Daniel is not always stressed. ${ }^{47}$ The reasons for this neglect are primary informed by two important factors. First, the diachronic studies of the two books have not allowed until in recent time, a literary/synchronic reading of the narrative elements in the two books. In modern scholarship, the dominance of historical investigation in the study of the two books has generally led to the neglect of important intertextual issues generated by the reading of the two books together. Secondly, the modern studies on the two books have not explored the intertextual character and relationship between the two books partly because of the bilingual character of Daniel which possibly undermine this intertextual bid. Consequently, this bilingual character and the additional apocalyptic genre of the book of Daniel have not allowed a study on the intertextual relationship between the two books.

Departing from these interests, one can show the intertextual relationships between the two books. In particular, the book of Esther and the narrative section of Daniel came from the same Persian period, and it is possibly to point to areas of similarities in motifs and plots within these two books. Several areas of these intertextual relationships are underscored here. First, the two books deployed the contest type-scene/motif in the characterization of the two heroes. In Esther, the beauty contest helps greatly in the representation of Esther as a

46 Wesselius, "The Writing of Daniel," 303.

47 Concerning the intertextual connection of the book of Esther to other biblical books, Carey A. Moore observed, "God may not be explicitly mentioned in the book of Esther, but its Jewish author was certainly familiar with the Hebrew Bible. Or at least, some scholars have seen Esther's style, content, plot as strongly influenced by a particular biblical book." See Carey A. Moore, Studies in the Book of Esther (New York: Ktav Publishing House, 1982), xliii. 
beautiful maiden whose beauty transcend all the women/virgins in the land. ${ }^{48}$ In the same way, in the opening of Daniel, there is a contest about healthylooking bodies between Daniel and his friends and the others young men eating from the royal table. There is invariably a healthy-looking body contest or even a body-building competition. According to the story, Daniel refuses the royal meals provided by the Babylonian king, and opted for vegetables. Afraid that eating vegetables alone will show on the body and performance of Daniel and his friends, Ashpenaz initially rejected this request. Daniel now asked for a contest whereby for 10 days, they will be feed on the vegetable diet and then at the end of these days they will be compared with their colleagues who eat the king's meals. After ten days, Daniel and his friends won the body-building contest because they appeared more healthy and well-built than their other colleagues. ${ }^{49}$ They won the body-beauty contest and emerged ten times healthier looking than other young men at the palace. Both Daniel and Esther emerged as characters through the means of a contest particularly connected to body building competition or a beauty pageant. ${ }^{50}$ They are the only characters in biblical narratives whose characterization and representation comes directly from the body/beauty contest. Secondly, the motif of bowing down to a statue or a person occupies an important place in the two books. In Esther, Mordecai refuses to bow down to Haman. It was this refusal to bow in respect before Haman that led to Haman's plot to destroy the entire Jewish people $(3: 1-6){ }^{51}$ Similarly, in Daniel, Shedrach, Meshech and Abnedgo also refuse to bow down to the great statue erected to be worshipped by king Nebuchadnezzar (3:130). ${ }^{52}$ It suffices to say that these two books are the only books in the HB where bowing down to an object or person played a cardinal role in the characterization of the characters in the book.

48 Michael Fox describes the "competition" in the book of Esther as a "beauty contest" in "the first stage of the process" but the actual competition is a "sex contest, with winner being whoever can most please the king during her night with him. Nothing but attractiveness to the king and sexual skills will, in this legendary account, determine who will become queen of Persia." See Michael Fox, Character and Ideology in the Book of Esther (Columbia, S.C.: University of South Carolina Press, 1991), 27-28.

49 Sibley Towner described this story of Daniel in terms of the "ideal courtiers" and connected Daniel to Joseph. See Sibley Towner, Daniel (IBC; Atlanta: John Knox Press, 1984), 21-24.

50 See Norman Porteous, Daniel (London: SCM, 1979), 28-33; Stephen R. Miller, Daniel (NAC 18; Nashville: Broadman \& Holman Publishers, 1994), 66-73.

51 Fox suggested the reason for Mordecai's refusal to bow before Haman was due to the perceived "tribal enmity" between the two characters. See Fox, Character and Ideology, 43-45.

52 Concerning the "bowing down" or worship of the statue see Miller, Daniel, 114116. 
Thirdly, the two books explore the motif of a sleepless king at a very important point in the characterization of the main character. In Esther, at the very morning when Haman sought to ask the king for the permission to execute Mordecai, the narrator reported that earlier the same night the king was unable to sleep $(6: 1-14) .{ }^{53}$ Similarly, Nebuchadnezzar's dream troubled his mind so that he could not sleep (2:1, cf. also 6:18). It was the telling and the interpretation of this particular dream that led to the first recognition of Daniel as a great seer or prophet in the book. Interestingly, these are the only occurrences in the entire HB where kings could not sleep in the night.

Fourth, the two books explore excessive banqueting motif as means for characterization. In Esther, the opening banquet receives a great description from the narrator. The banquet itself causes the fall of Vashti and the exaltation of Esther. ${ }^{54}$ In almost the same way, in Daniel 5, there is a great preoccupation with banquet of king Belshazzar which also lead to his downfall and the exaltation of Daniel. In both two stories queens played an important part in the plot of the story. In the book of Esther, Vashti's refusal to come to the king when summoned led to her downfall, and in the book of Daniel, the queen mother came without been summoned, and she orchestrated events that subsequently led to the king's summon of Daniel, the interpretation of the writings on the wall by him, and his immediate exaltation by the king. These are the only detailed descriptive banquets in the HB where queens played a cardinal role in the characterizations within the stories.

Similarly, the two stories employed the plot of allegations and conspiracy by a royal officer or officials with the intent to kill the main character of the story. In the book of Esther, Haman, a royal officer hated Mordecai and brought allegations against the entire Jewish people. He uses his power and influence at the court to plan the massacre of the Jewish people (3:1-15). In almost the same way, the government officials and administrators connived together and came to the king with the request that for 30 days nobody will pray to any God except the king (Dan 6). This incidence also led to the throwing of Daniel into the lion's den. In both of these stories, a government official or officials used his/their positions at the court in order to incite the king against the main character, or his people. These two stories are the only stories in the biblical narratives whereby a royal official or a group of royal officers incited the king against a particular individual or a group of people.

In addition, to all these shared motifs between the two books, there is the reference in the two books to the laws of the Medes and Persians which cannot be revoked or repealed. These are the two books in the entire HB in which a

53 Fox, Character and Ideology, 75-76.

54 Concerning the banqueting motifs in Esther and its significance see Trisha G. Wheelock, Drunk and Disorderly: A Bakhtinian Reading of the Banquet Scenes in Esther (Ann Arbor, Mich.: ProQuest LCC, 2009), 85-195. 
reference to the laws of the Medes and Persia as irrevocable is emphasized. In the story of Daniel in the lion's den there were references to these particular laws $(6: 8,12,15) .{ }^{55}$ In the same way, the book of Esther also made references to this law $(1: 19,8: 10) .{ }^{56}$ Concerning these laws, Michael Fox observed, " $[\mathrm{t}] \mathrm{he}$ notion that the Persians and Medes could not repeal their own laws, even ad hoc decrees, is an essential presupposition in the biblical book of Esther. It is found elsewhere only in Daniel $(6: 8,12,15) .{ }^{, 57}$

From the foregoing, the book of Esther and the narrative section of Daniel (1-6) appear to have shared interests in the key issues raised within the two books. In this sense, there is an intertextual link which directly cuts across the stories and thereby bridging the interests of the two books. While the degree of this narrative awareness between the two books cannot be ascertained, it appears the books engaged similar problems in the world of the authors. Ironically, this perceived similarity between the two books also hides an important difference especially in the individual expressions and mapping of their concealed polemics.

\section{CONCLUSION}

The books of Esther and Daniel appear to use common and shared literary conventions and motifs. The two books are situated in the same narrative milieu of the postexilic discourse, and the shared motifs in the two books appear to have been drawn from a common Persian source. On the other hand, one may perceive the common theme and the refractions of these themes within these two books in terms of polemics whereby one book seeks to promote, engage or even undermine the rhetoric of the other book. In this regard, one can perceive Daniel as written in order to counteract the representations of the Jewish communities in Esther with the polemics of Daniel (1-6) subtly pitched against Esther. ${ }^{58}$ It seems Daniel seeks to undermine or challenge the ideology in the book of Esther. For example, Esther was involved in a sexual contest, married a

\footnotetext{
55 Miller, Daniel, 181-182.

56 For the character of Achaemenid rule and the impact of its legislations see Josef Wiesehöfer, "Achaemenid Rule and Its Impact on Yehud," in Texts, Contexts and Readings in Postexilic Literature (ed. Louis Jonker; Tübingen, Germany: Mohr Siebeck, 2011), 171-185.

57 Fox added, this particular conception of Persian laws “...is not attested in Persian or Greek sources, and it seems an impossible rule for running an empire." See Fox, Character and Ideology, 22.

58 Michael Fox has drawn attention to the different ways which ancient and modern interpreters have viewed the character of Esther. In particular, Fox has presented three different types of Esther in the Masoretic, the Alpha Text, and the Septuagint texts. Concerning these different characterizations of Esther see Michael Fox, "Three Esthers," in The Book of Esther in Modern Research (ed. Sidnie W. Crawford and Leonard J. Greenspoon; London: T \& T Clark, 2003), 50-60.
} 
pagan king, defiled herself with the excessive luxuries of the Persian court, and there is no recorded complaint about abstaining herself from the royal meals or banquet. ${ }^{59}$ In fact, she hosted twice a royal banquet, thus eating with the king and the enemy of the Jews namely Haman. ${ }^{60}$ In contrast, Daniel refused to defile himself with the king's meal; he refused to comply with the edict to stop praying to any deity for 30 days, and he implicitly refused the use of his pagan name Belteshazzar (1:7) since the narrator refused the use of this name for Daniel in the entire narrative. However, Esther refused the use of her Hebrew name Hadassah and adopted her Persian name "Esther" (2:7) ${ }^{61}$ The narrator consistently used the Persian name for his heroine (7:3), and refused to use the Hebrew name for her.

Similarly, the book of Esther has generated great theological debates about the absence of God's name. In contrast, it seems the narrator of Daniel wanted to bring back God into the discourse of the postexilic community particularly in his emphasis on divine activities, causation and sovereignty over the affairs of human beings. This particular emphasis directly undermines the rhetoric of the book of Esther where the deity has no clear foothold. Importantly, the book of Daniel moves away from the propaganda and the acceptance of the cultures and practices of the host country in Esther, thus providing multiple perspectives to the problems of Jewish identity in postexilic environment. Describing the contesting and multiple perspectives in the writings of the postexilic society, Ehud Ben Zvi observed,

59 Barry D. Walfish describes this troubling sexual union in the discourse of Jewish rabbis. For this study see Barry D. Walfish, "Kosher Adultery? The MordecaiEsther-Ahasuerus Triangle in Talmudic, Medieval and Sixteenth-Century Exegesis," in The Book of Esther in Modern Research (ed. Sidnie W. Crawford and Leonard J. Greenspoon; London: T \& T Clark, 2003), 111-136. Also see Barry D. Walfish, Esther in Medieval Garb: Jewish Interpretation of Esther in the Middle Ages (Albany: State University of New York Press, 1993), 3-9; Jonathan Grossman, Esther: The Outer Narrative and the Hidden Reading (Winona Lake: Eisenbrauns, 2011), 66-67.

60 Concerning the moral problem in the book of Esther, Charles D. Harvey said, "[p]erhaps mirroring the troubles faced by Jews in the perilous Diaspora of the Esther story and beyond, the way travelled by the book of Esther has been fraught with difficulties and misunderstandings..." Harvey describes the various moral problems generated by the characterization, plots and mapping of the stories in Esther. For this study see Charles D. Harvey, Finding Morality in the Diaspora: Moral Ambiguity and Transformed Morality in the Books of Esther (Berlin: Walter de Gruyter, 2003), 1, 1977.

61 According to Jean-Daniel Macchi, "[t]he book of Esther is a novel set in the Persian Empire..." but it adopts Greek style. This convergence of Persian, Greek and Jewish concerns raises important issues in the reading of the book of Esther. See JeanDaniel Macchi, "The Book of Esther: A Persian Story in Greek Style," in Texts, Contexts and Readings in Postexilic Literature (ed. Louis Jonker; Tübingen: Mohr Siebeck, 2011), 109-128. 
From a system's perspective, it is clear that there was a strong preference for the presence of multiple voices and for a collective memory that included vast arrays of seemingly contradictory memories (and thus and by implication, a de-emphasising of the mimetic aspect of memory and historiography). An Israel that imagined itself through the reading of the authoritative literature of the late Persian period was an Israel that imagined itself as constantly balancing and thus integrating different viewpoints, memories, statements and even law texts. This is an Israel in which texts kept informing other texts and in which, within limits to be sure, multiple perspectives were allowed. ${ }^{62}$

This late Persian literary environment allowed for "multiple views" in the interpretations, understanding, and formation of the Jewish identity. It was in this "multi-layered" milieu in the "self-understanding of Israel" that the particular ideological interests in Esther and Daniel were clearly formed. Seen from this perspective, the book of Daniel (1-6) engages Esther, and appears to subtly challenge the uncritical adoption of the Persian culture of the host country. The narrative section of Daniel (1-6) directly frowned at the general assimilation of the Jewish communities in Esther, and directly undermine the dominant removal of the sacred in its narrative space by the extreme recognition of the sacred where even pagan kings like Nebuchadnezzar acknowledged the superiority of Yahweh. In this regard, Daniel represents a narrative space dominated with divine presence and sovereignty. The entire human history is placed in periodic manner and Yahweh's dominion asserted on these different periods. In these postexilic communities, some like Esther advocated the hiding of the Jewish identity, and thus the accommodation of the culture and way of life of the host country. However, others like Daniel promote the flaunting of the Jewish identity in kosher observances, refusal to compromise in idolatry, and the general advocacy of Jewish piety in terms of prayers and fidelity to the faith of the fathers. Ironically, while Daniel opens his window towards Jerusalem, Esther seeks the opening of doors to enter Ahasuerus's presence. While Esther gives banquets, Daniel refrains from the royal banquets and meals. In the same way, while Daniel flaunts his Jewishness from the opening of the book, Esther hides her Jewish identity more than half of the book (7:3).

Based on these similarities and subtle polemics between the two books, one could humorously ask why not Esther in the lion's den, and Daniel at the beauty pageant? Or in another comic sense, why not Esther on the kosher diet, and Daniel among Babylonian women? Why not Esther as the interpreter of the king's dreams and Daniel at the king's harem? Why is it that a central stage is given to Esther's marriage to a pagan king by the narrator of Esther, and the

62 See Ehud Ben Zvi, "On Social Memory and Identity Formation in Late Persian Yehud," in Texts, Contexts and Readings in Postexilic Literature (ed. Louis Jonker; Tübingen: Mohr Siebeck, 2011), 95-148, quotation page 141. 
narrator of Daniel ignored throughout the book the marital status of Daniel? By the use of the specific means of characterizations found in the two books, the two authors of the books appear to speak to the ideological world of the Persian societies where the two ideologies of assimilation, and subversive resistance dominate. The mapping of the stories in these two books engages two different ideologies within the postexilic communities and to contemporary context whether to hide one's religious and ethnic identities as largely carried out in the book of Esther or to flaunt these identities as advocated in the book of Daniel.

\section{BIBLIOGRAPHY}

Adelman, Diana. "Hidden Ancestral Polemics in the Book of Genesis." Pages 35-56 in Words, Ideas, and World. Edited by Athalya Brenner and Frank H. Polak. Sheffield: Phoenix, 2012.

Alter, Robert. The Art of Biblical Narrative. New York: Basic Books, 2011.

Amit, Yairah. Hidden Polemics in Biblical Narrative. Biblical Interpretation 25. Translated by Jonathan Chipman. Leiden: Brill, 2000.

Ben Zvi, Ehud. "On Social Memory and Identity Formation in Late Persian Yehud." Pages 95-148 in Texts, Contexts and Readings in Postexilic Literature. Edited by Louis Jonker. Tübingen: Mohr Siebeck, 2011.

Berger, Yitzhak. "Esther and Benjaminite Royalty: A Study in Inner-Biblical Allusion." Journal of Biblical Literature 129/4 (2010): 253-272.

Biddle, Mark. "Ancestral Motifs in 1 Samuel 25: Intertextuality and Characterization." Journal of Biblical Literature 121/4 (2002): 617-638.

Collins, John J. Daniel: A Commentary on the Book of Daniel. Hermeneia. Minneapolis: Fortress, 1993.

Edenburg, Cynthia. "Intertextuality, Literary Competence, and the Question of Readership: Some Preliminary Observations." Journal for the Study of the Old Testament 35/4 (2010): 131-148.

Firth, David G. "When Samuel Meets with Esther: Narrative Focalisation, Intertextuality, and Theology." Southeastern Theological Review 1/1 (2010): $15-28$.

Fox, Michael. Character and Ideology in the Book of Esther. Columbia, S.C.: University of South Carolina Press, 1991. . "Three Esthers." In The Book of Esther in Modern Research. Edited by Sidnie W. Crawford and Leonard J. Greenspoon. London: T \& T Clark, 2003.

Freedman, Amelia D. God as an Absent Character in Biblical Hebrew Narrative: A Theoretical Study. Studies in Biblical Literature 82. New York: Peter Lang, 2005.

Gerleman, Gillis. Esther. Biblischer Kommentar, Altes Testament 21. NeukirchenVluyn: Neukirchener Verlag, 1966.

. Studien zu Esther. Biblische Studien (Neukirchen, 1951-) 48. NeukirchenVluyn, 1974.

Gnuse, Robert K. "The Jewish Dream Interpreter in a Foreign Court: The Recurring Use of a Theme in Jewish Literature." Journal for the Study of the Pseudepigrapha7 (1990): 29-53.

Grossman, Jonathan. Esther: The Outer Narrative and the Hidden Reading. Winona Lake: Eisenbrauns, 2011. 
Michael, "Daniel at the Beauty Pageant," OTE 29/1 (2016): 116-132

Hartman, Louis F. and Alexander A. Di Leila. The Book of Daniel: A New

Translation with Introduction and Commentary. Anchor Bible 23. New York:

Doubleday, 1978.

Harvey, Charles D. Finding Morality in the Diaspora: Moral Ambiguity and

Transformed Morality in the Books of Esther. Berlin: Walter de Gruyter, 2003.

Humphreys, W. Lee. "A Life-Style for Diaspora: A Study of the Tales of Esther and

Daniel." Journal of Biblical Literature 92 (1973): 211-23.

Kee, Min S. "The Heavenly Council and its Type-scene." Journal for the Study of the Old Testament 31/3 (2007): 257-273.

Koller, Aaron. Esther in Ancient Thought. New York: Cambridge University Press, 2014.

Loader, James A. "Intertextuality in Multi-Layered Texts of the Old Testament." Old Testament Essays 21/2 (2008): 391-403.

Macchi, Jean-Daniel. "The Book of Esther: A Persian Story in Greek Style." Pages 109-128 in Texts, Contexts and Readings in Postexilic Literature. Edited by Louis Jonker. Tübingen: Mohr Siebeck, 2011.

McKay, Niall. "Status Update: The Many Faces of Intertextuality in New Testament Study." Religion \& Theology 20 (2013): 84-106.

Miller, Geoffrey D. "Intertextuality in Old Testament Research." Currents in Biblical Research 9/3 (2010): 283-309.

Miller, Stephen R. Daniel. The New American Commentary 18. Nashville: Broadman \& Holman publishers, 1994.

Moore, Carey A. Studies in the Book of Esther. New York: Ktav Publishing House, 1982.

Pyper, Hugh S. "Reading in the Dark: Zechariah, Daniel and the Difficulty of Scripture." Journal for the Study of the Old Testament 29/4 (2005): 485-504.

Porteous, Norman. Daniel. London: SCM, 1979.

Rindge, Matthew S. "Jewish Identity under Foreign Rule: Daniel 2 as a Reconfiguration of Genesis 41." Journal of Biblical Literature 129/1 (2010): 85-104.

Rogland, Max. "Interpreting אר in Genesis 2.5-6: Neglected Rabbinic and Intertextual Evidence," Journal for the Study of the Old Testament 34/4 (2010): 379-393.

Scheinerman, Amy. "Exodus, Esther and Maccabees in Conversation: 'They Tried to Kill us; We Survive; Let's Eat." CCAR Journal: The Reform Jewish Quarterly (2013): 3-23.

Segal, Michael. "From Joseph to Daniel: The Literary Development of the Narrative in Daniel 2." Vetus Testamentum 59 (2009): 123-149.

Seow, Choon-Leong. Daniel. Westminster Bible Companion. Louisville: Westminster John Knox, 2003.

Shakib, Mohammed K. "Inevitability of Arts from Inter-textuality." International Journal of English and Literature 4/1 (2013): 1-5.

Shalom-Guy, Hava. "Three-Way Intertextuality: Some Reflections of Abimelech's Death at Thebez in Biblical Narrative." Journal for the Study of the Old Testament 34/4 (2010): 419-432.

Swart, Gerhard J. "Rahab and Esther in Josephus: An Intertextual Approach." Acta Patristica et Byzantica 17 (2006): 50-65.

Towner, Sibley. Daniel. Interpretation: A Bible Commentary for Teaching and Preaching. Atlanta: John Knox Press, 1984. 
132 Michael, "Daniel at the Beauty Pageant," OTE 29/1 (2016): 116-132

Trull, Patricia. "Intertextuality and the Hebrew Scriptures." Currents in Biblical Research 8 (2000): 59-90.

Walfish, Barry D. Esther in Medieval Garb: Jewish Interpretation of Esther in the Middle Ages. Albany: State University of New York Press, 1993.

. "Kosher Adultery? The Mordecai-Esther-Ahasuerus Triangle in Talmudic, Medieval and Sixteenth-Century Exegesis." Pages 111-136 in The Book of Esther in Modern Research. Edited by Sidnie W. Crawford and Leonard J. Greenspoon. London: T \& T Clark, 2003.

Wesselius, Jan-Wim. "The Writing of Daniel." Pages 291-310 in The Book of Daniel: Composition and Reception. Edited by John J. Collins and Peter W. Flint. Leiden: Brill, 2001.

Wheelock, Trisha G. Drunk and Disorderly: A Bakhtinian Reading of the Banquet Scenes in Esther. Ann Arbor, Mich.: ProQuest LCC, 2009.

Wiesehöfer, Josef. "Achaemenid Rule and Its Impact on Yehud." Pages , 171-185 in Texts, Contexts and Readings in Postexilic Literature. Edited by Louis Jonker. Tübingen: Mohr Siebeck, 2011.

Wildavsky, Aaron. Assimilation versus Separation: Joseph the Administrator and the Politics of Religion in Biblical Israel. New Brunswick, N.J.: Transaction, 1993.

Dr. Matthew Michael lectures at the Department of Christian Religious Studies, Faculty of Arts, Nasarawa State University, Nigeria. Research fellow, Department of Old and New Testaments, Faculty of Theology, Stellenbosch University, South Africa. Email: rabbimikhail@yahoo.com. 